\title{
Effects of Irrigation and Foliar Nutrition on Growth, Yield and Nutrient Uptake of Blackgram (Vigna mungo L.)
}

\author{
Kaviti Vijaya Lakshmi*, S. Prathibha Sree, N. Venkata Lakshmi, \\ P. Madhu Vani and K. Chandrasekhar
}

Department of Agronomy (Water Management), Advanced Post Graduate Centre, Acharya N. G. Ranga Agricultural University, Lam, Guntur-522034, India

*Corresponding author

\begin{tabular}{|c|c|}
\hline & A B S T R A C T \\
\hline Keywords & \multirow{4}{*}{$\begin{array}{l}\text { A field experiment was conducted on sandy loam soils of Agricultural Research Station, } \\
\text { Jangamaheswarapuram during rabi, 2016-17 to study the effect of irrigation and foliar } \\
\text { nutrition on growth, yield and nutrient uptake of blackgram. The experiment was laid out } \\
\text { in split plot design and replicated thrice. The treatments comprised of four main plots viz, } \\
\text { No irrigation }\left(\mathrm{I}_{1}\right) \text {, Irrigation at } 0.3 \mathrm{IW} / \mathrm{CPE}\left(\mathrm{I}_{2}\right), 0.4 \mathrm{IW} / \mathrm{CPE}\left(\mathrm{I}_{3}\right) \text { and } 0.5 \mathrm{IW} / \mathrm{CPE}\left(\mathrm{I}_{4}\right) \\
\text { ratios and four sub plot treatments viz., foliar spraying of } 2 \% \text { urea }\left(\mathrm{F}_{1}\right), 2 \% \mathrm{DAP}\left(\mathrm{F}_{2}\right), 1 \% \\
\mathrm{KNO}_{3}\left(\mathrm{~F}_{3}\right) \text { and } 2 \% 19-19-19\left(\mathrm{~F}_{4}\right) \text { twice at pre-flowering pod filling stages. Among the } \\
\text { main plot treatments, irrigation given at vegetative stage }(33 \mathrm{DAS}) \mathrm{i} \text {.e, } 0.5 \mathrm{IW} / \mathrm{CPE} \text { ratio } \\
\text { was found to be better in improving growth, yield parameters and more nutrient uptake } \\
\text { over other irrigation treatments. Among, sub plot treatments } 1 \% \text { KNO } \mathrm{K}_{3} \text { twice at pre- } \\
\text { flowering and pod filling stages }\left(\mathrm{F}_{3}\right) \text { recorded significantly the highest growth and yield of } \\
\text { blackgram when compared with other foliar treatments. }\end{array}$} \\
\hline $\begin{array}{l}\text { Blackgram, Foliar } \\
\text { nutrition, Growth, } \\
\text { Irrigation, Nutrient } \\
\text { uptake, Yield }\end{array}$ & \\
\hline Article Info & \\
\hline $\begin{array}{l}\text { Accepted: } \\
\text { 20 May } 2018 \\
\text { Available Online: } \\
\text { 10 June } 2018\end{array}$ & \\
\hline
\end{tabular}

\section{Introduction}

Pulses are wonderful gift of nature with unique ability of biological nitrogen fixation, deep root system, mobilization of insoluble soil nutrients and bringing qualitative changes in soil properties. Blackgram (Vigna mungo L.), also known as urd bean, mash and black maple is a short duration pulse crop grown in many parts of India. It is one of the highly prized pulse crops with regard to its antiquity and its use as a source of human food. Blackgram seed contains 25-26\% proteins, 60 $\%$ carbohydrates, $1.5 \%$ fat and minerals combination, aminoacids and essential vitamins. India is the largest producer as well as consumer of blackgram which accounts for about 10 per cent of India's total pulse production. The World Health Organization recommended as per capita consumption of pulses at $80 \mathrm{~g} \mathrm{day}^{-1}$. But at present the per capita availability of pulses is only $40 \mathrm{~g}_{\text {day }}{ }^{-1}$ in India. In Andhra Pradesh, blackgram is grown in an area of 3.17 lakh ha with a production of 2.16 lakh tonnes and productivity of $866 \mathrm{~kg} \mathrm{ha}^{-1}$ during the year 2015-16 (Agriculture action plan 2015-16, Department of Agriculture, A.P). Rice - 
blackgram cropping system is famous in Guntur District of Andhra Pradesh. In kharif, it is grown in 0.19 lakh ha, producing 0.21 lakh tonnes with a productivity of $1079 \mathrm{~kg} \mathrm{ha}^{-}$ ${ }^{1}$. In rabi, it occupies 2.98 lakh ha, producing 1.95 lakh tonnes with a productivity of $653 \mathrm{~kg}$ $\mathrm{ha}^{-1}$ (Department of Agriculture and Cooperation, Government of Andhra Pradesh. 2015).

Therefore, present research is carried out to improve the productivity of blackgram through irrigation and foliar nutrition with chemicals like $2 \%$ urea, $2 \%$ DAP, $2 \% \mathrm{KNO}_{3}$ and 2\% 19-19-19 inorder to enhance the productivity by improving growth and yield parameters of blackgram.

\section{Materials and Methods}

In present study, seed of PU-31 variety was used. The experiment was conducted on sandy loam soils of Agricultural Research Station, Jangamaheswarapuram during rabi, 2016-17 to study the Effect of irrigation and foliar nutrition on growth, yield and nutrient uptake of blackgram (Vigna mungo L.).

The experiment was laid out in split plot design and replicated thrice with four irrigation levels viz., $\mathrm{I}_{1}$ - Control, $\mathrm{I}_{2}$-Irrigation at $0.3 \mathrm{IW} / \mathrm{CPE}, \mathrm{I}_{3}$ - Irrigation at $0.4 \mathrm{IW} / \mathrm{CPE}$ and $\mathrm{I}_{4}$ - Irrigation at $0.5 \mathrm{IW} / \mathrm{CPE}$ ratios as main plots and four foliar spray treatments $\mathrm{F}_{1}$ $-2 \%$ urea, $\mathrm{F}_{2}-2 \% \mathrm{DAP}, \mathrm{F}_{3}-1 \% \mathrm{KNO}_{3}$ and $\mathrm{F}_{4}-2 \%$ 19-19-19 applied twice at pre flowering and pod filling stages as sub plots.

The soil of the experimental area was sandy loam with $\mathrm{p}^{\mathrm{H}} 8.51$, low in organic carbon $(0.38 \%)$ and available nitrogen $\left(140 \mathrm{~kg} \mathrm{ha}^{-1}\right)$, high in phosphorus $\left(54 \mathrm{~kg} \mathrm{ha}^{-1}\right)$ and potassium $\left(436 \mathrm{~kg} \mathrm{ha}^{-1}\right)$. Recommended dose of fertilizer @ $20 \mathrm{~kg} \mathrm{~N} \mathrm{ha}{ }^{-1}$ and $50 \mathrm{~kg} \mathrm{P}_{2} \mathrm{O}_{5} \mathrm{ha}^{-1}$ was applied uniformly to all the experimental plots at the time of sowing as basal.

\section{Results and Discussion}

\section{Growth}

Plant height of blackgram was found to be non-significant with respect of irrigation levels and foliar nutrition treatments. The highest plant height was recorded with irrigation at $0.5 \mathrm{IW} / \mathrm{CPE}(15.7,19.9,28.3$, 33.1 and $34.1 \mathrm{~cm}$ ) followed by irrigation at 0.4 IW/CPE and 0.3 IW/CPE ratios and the lowest plant height was recorded in control plot $(14.1,18.4,25.4,29.6$ and $30.6 \mathrm{~cm})$ at 15,30 , 45, 60 and 75 DAS.. The influence of irrigation and foliar nutrition on number of branches plant ${ }^{-1}$ was found to be significant at 45, 60 and 75 DAS except at 30 DAS. The highest number of branches plant ${ }^{-1}$ was recorded at 0.5 IW/CPE (4.4, 6.2, 6.4 and 6.9) at all the growth stages but at 30 DAS the difference was found to be non-significant. The influence of foliar nutrition on plant height of blackgram was found to be nonsignificant at all the growth stages of crop. The highest plant height of 15.3, 19.4, 27.3, 31.8 and $32.8 \mathrm{~cm}$ was recoeded with foliar spray of $1 \% \mathrm{KNO}_{3}$. A significant influence of foliar nutrition on number of branches plant ${ }^{-1}$ was observed at 45, 60 and 75 DAS but not at 30 DAS. Foliar application of $1 \% \mathrm{KNO}_{3}$ recorded significantly the highest number of branches plant ${ }^{-1}(4.2,6.2,6.5$ and 7.0$)$ at 30, 45, 60 and 75 DAS. At 45 DAS $1 \% \mathrm{KNO}_{3}$ recorded the highest number of branches plant ${ }^{-}$ ${ }^{1}$ but was on a par with $2 \%$ DAP and $2 \% 19$ 19-19. The lowest number of branches plant ${ }^{-1}$ was recorded with $2 \%$ urea at all the growth stages. The increase in plant height and more number of branches is due to the additional supply of nutrients through foliar application which might have increased nutrient uptake and better translocation of nutrients. Similar results were reported by Subramani and Solaimalai (2000) and Parasuraman (2001). The dry matter production at various growth stages clearly indicated that there is a gradual 
increase in dry matter production with duration of the crop. At all the stages of crop growth the highest dry matter production was recorded at $0.5 \mathrm{IW} / \mathrm{CPE}$ ratio $(218,576,857$, 3322 and $3793 \mathrm{~kg} \mathrm{ha}{ }^{-1}$ ) which was significantly superior to all other irrigation treatments. The influence of foliar nutrition on dry matter production of blackgram was found to be significant at all the growth stages of the crop. Foliar spraying of $1 \% \mathrm{KNO}_{3}$ recorded the maximum dry matter production (192, 488, 837, 2735 and $3206 \mathrm{~kg} \mathrm{ha}^{-1}$ ). At 75 DAS, foliar spray with $1 \% \mathrm{KNO}_{3}$ was comparable with $2 \%$ DAP and $2 \%$ 19-19-19. The interaction effect of irrigation levels and foliar nutrition on dry matter production was found to be non-significant at all the stages of crop growth. Increased dry matter production in leaf, stem, reproductive parts and total dry matter at harvest was mainly due to additional foliar application of water soluble fertilizers which led to increased uptake of nutrients which in turn helped in increased plant height and number of branches. This contributed for better plant growth and ultimately increased the dry matter production. These results are in confirmation with the findings of Thiyageswari and Ranganathan (1999), Anbumani et al., (2003). These results are in confirmation with the results of Jayarami Reddy et al., (2004).

\section{Yield}

The data recorded on yield attributes indicated that the influence of irrigation and foliar nutrition treatments on number of clusters plant $^{-1}$ and test weight was found to be significant. But the significant difference in yield attributes such as number of pods cluster $^{-1}$ and seeds pod ${ }^{-1}$ were not noticed. The maximum number of yield attributes such as number of clusters plant ${ }^{-1}$, pods cluster ${ }^{-1}$ and seeds pod $^{-1}$ was recorded in $0.5 \mathrm{IW} / \mathrm{CPE}$ (3.8, 6.2 and 6.3) and minimum were recorded in no irrigated treatment (2.9, 5.9 and 6.0). Among foliar treatments, $1 \% \mathrm{KNO}_{3}$ recorded maximum yield attributing parameters like as number of clusters plant ${ }^{-1}$, pods cluster ${ }^{-1}$ and seeds $\operatorname{pod}^{-1}$ (3.7, 6.1 and 6.3). The interaction effect of irrigation and foliar nutrition on test weight of blackgram was found to be significant. Significantly the highest mean maximum test weight was recorded with $\mathrm{I}_{4} \mathrm{~F}_{3}$ (Irrigation at $0.5 \mathrm{IW} / \mathrm{CPE}$ along with $1 \%$ $\left.\mathrm{KNO}_{3}\right)(50.2 \mathrm{~g})$ and was on a par with $\mathrm{I}_{4} \mathrm{~F}_{2}$ $(49.2 \mathrm{~g})$ and the lowest mean maximum test weight was recorded with $\mathrm{I}_{1} \mathrm{~F}_{1}$ (No irrigation plot along with $2 \%$ urea) treatment (36.2 g). On the contrary, the lowest test weight with lower irrigation frequency might be due to the effect of soil moisture stress leading to poor translocation of photosynthates resulting in shrivelled and small sized seeds. Similar findings were reported by Dabhi et al., (1998) and Mustafa et al., (2008).

The highest seed yield was recorded in 0.5 IW/CPE (959 kg ha ${ }^{-1}$ ) and it was significantly superior to all other irrigation treatments. With respect to haulm yield the highest haulm yield was recorded with $0.5 \mathrm{IW} / \mathrm{CPE}$ (1935 $\mathrm{kg} \mathrm{ha}^{-1}$ ) which was comparable with irrigation at 0.4 IW/CPE $\left(1750 \mathrm{~kg} \mathrm{ha}^{-1}\right)$. The lowest seed and haulm yield were recorded in no irrigated plot (610 and $\left.1356 \mathrm{~kg} \mathrm{ha}^{-1}\right)$. Foliar spraying of $1 \%$ $\mathrm{KNO}_{3}$ twice at pre-flowering and pod filling stages recorded the highest seed yield $(833 \mathrm{~kg}$ $\mathrm{ha}^{-1}$ ) which was on a par with $2 \%$ DAP (782 $\mathrm{kg} \mathrm{ha}^{-1}$ ) and the lowest seed yield was recorded with $2 \%$ urea $\left(704 \mathrm{~kg} \mathrm{ha}^{-1}\right)$ but on a par with 2 $\%$ 19-19-19 (749 $\left.\mathrm{kg} \mathrm{ha}^{-1}\right)$. The highest haulm yield was recorded with $1 \% \mathrm{KNO}_{3}(1828 \mathrm{~kg}$ $\mathrm{ha}^{-1}$ ) which was significantly superior to all other foliar treatments. The influence of irrigation and foliar nutrition on harvest index of blackgram was found to be non-significant. The interaction effect of irrigation levels and foliar nutrition on yield attributes, yield and harvest index of blackgram was found to be non-significant. These results are also in conformity with the findings of Krishnamurthy and Ramulu (2007), Beg et al., (2013) and Kadam et al., (2008). 
Table.1 Effect of irrigation and foliar nutrition on growth parameters of blackgram at harvest

\begin{tabular}{|c|c|c|c|c|}
\hline \multirow{2}{*}{\multicolumn{2}{|c|}{ Treatment }} & \multicolumn{3}{|c|}{ Growth parameters at harvest } \\
\hline & & $\begin{array}{l}\text { Plant height } \\
\text { (cm) }\end{array}$ & $\begin{array}{l}\text { No.of branches } \\
\text { plant }^{-1}\end{array}$ & $\begin{array}{l}\text { Dry matter production } \\
\left(\mathrm{kg} \mathrm{ha}^{-1}\right)\end{array}$ \\
\hline \multicolumn{5}{|c|}{ Irrigation levels } \\
\hline$I_{1}$ & Control & 30.6 & 6.1 & 2414 \\
\hline$I_{2}$ & $0.3 \mathrm{IW} / \mathrm{CPE}$ ratio & 31.7 & 6.5 & 2656 \\
\hline $\mathbf{I}_{3}$ & $0.4 \mathrm{IW} / \mathrm{CPE}$ ratio & 32.1 & 6.7 & 3353 \\
\hline \multirow[t]{4}{*}{$\mathbf{I}_{4}$} & $0.5 \mathrm{IW} / \mathrm{CPE}$ ratio & 34.1 & 6.9 & 3793 \\
\hline & SEm \pm & 1.11 & 0.14 & 85.5 \\
\hline & $\mathrm{CD}(\mathrm{p}=0.05)$ & NS & 0.49 & 295.8 \\
\hline & CV $(\%)$ & 11.9 & 7.5 & 9.7 \\
\hline \multicolumn{5}{|c|}{ Foliar spray } \\
\hline $\mathbf{F}_{1}$ & $2 \%$ Urea & 31.6 & 6.2 & 2904 \\
\hline$\overline{F_{2}}$ & $2 \%$ DAP & 32.2 & 6.5 & 3041 \\
\hline $\mathrm{F}_{3}$ & $1 \% \mathrm{KNO}_{3}$ & 32.8 & 7.0 & 3206 \\
\hline \multirow[t]{5}{*}{$F_{4}$} & $2 \% 19-19-19$ & 31.8 & 6.4 & 3066 \\
\hline & $\mathrm{SEm} \pm$ & 1.22 & 0.16 & 67.9 \\
\hline & CD $(p=0.05)$ & NS & 0.46 & 198.2 \\
\hline & CV $(\%)$ & 13.1 & 8.4 & 7.7 \\
\hline & Interaction & NS & NS & NS \\
\hline
\end{tabular}

Table.2 Effect of irrigation and foliar nutrition on yield attributes of blackgram

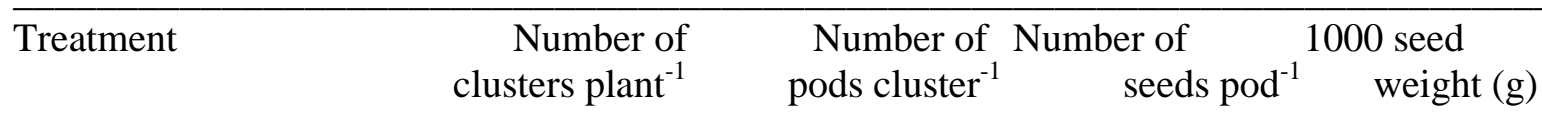

Irrigation levels:

$\mathrm{I}_{1}$-Control

$\mathrm{I}_{2}-0.3 \mathrm{IW} / \mathrm{CPE}$ ratio

$\mathrm{I}_{3}-0.4 \mathrm{IW} / \mathrm{CPE}$ ratio

$\mathrm{I}_{4}-0.5 \mathrm{IW} / \mathrm{CPE}$ ratio

$\mathrm{SEm} \pm$

$\mathrm{CD}(\mathrm{p}=0.05)$

CV (\%)

Foliar spray:

$\mathrm{F}_{1}-2 \%$ urea

$\mathrm{F}_{2}-2 \%$ DAP

$\mathrm{F}_{3}-1 \% \mathrm{KNO}_{3}$

$\mathrm{F}_{4}-2 \%$ 19-19-19

$\mathrm{SEm} \pm$

$\mathrm{CD}(\mathrm{p}=0.05)$

$\mathrm{CV}(\%)$

Interaction $(\mathbf{I} \times \mathbf{F})$ :

SEm \pm

$\mathrm{CD}(\mathrm{p}=0.05)$
2.9

3.5

3.7

3.8

0.06

0.21

6.1

3.4

3.5

3.7

3.5

0.09

0.27

9.4

0.16

NS
5.9

6.1

6.0

6.2

0.14

NS

8.1

6.0

5.9

6.1

5.8

0.16

NS

9.1

0.32

NS
6.0

6.2

6.1

6.3

0.17

NS

9.7

6.2

6.1

6.3

6.0

0.19

NS

10.8

0.39

NS
44.2

46.9

47.2

48.9

0.45

1.54

3.3

44.8

47.5

48.0

46.9

0.22

0.64

1.6

0.44

1.28 
Table.3 Effect of irrigation and foliar nutrition on yield of blackgram

\begin{tabular}{|c|c|c|c|}
\hline Treatment & $\begin{array}{c}\text { Seed yield } \\
\left(\mathrm{kg} \mathrm{ha}^{-1}\right)\end{array}$ & $\begin{array}{c}\text { Haulm yield } \\
\left(\mathrm{kg} \mathrm{ha}^{-1}\right)\end{array}$ & $\begin{array}{l}\text { Harvest } \\
\text { index }(\%)\end{array}$ \\
\hline \multicolumn{4}{|l|}{ Irrigation levels: } \\
\hline $\mathrm{I}_{1}$-Control & 610 & 1356 & 31.1 \\
\hline $\mathrm{I}_{2}-0.3 \mathrm{IW} / \mathrm{CPE}$ ratio & 710 & 1604 & 30.8 \\
\hline $\mathrm{I}_{3}-0.4 \mathrm{IW} / \mathrm{CPE}$ ratio & 790 & 1750 & 31.2 \\
\hline $\mathrm{I}_{4}-0.5 \mathrm{IW} / \mathrm{CPE}$ ratio & 959 & 1935 & 33.2 \\
\hline $\mathrm{SEm} \pm$ & 21 & 61 & 0.81 \\
\hline $\mathrm{CD}(\mathrm{p}=0.05)$ & 74 & 212 & NS \\
\hline $\mathrm{CV}(\%)$ & 9.7 & 12.8 & 8.8 \\
\hline \multicolumn{4}{|l|}{ Foliar spray: } \\
\hline$F_{1}-2 \%$ urea & 704 & 1618 & 30.3 \\
\hline $\mathrm{F}_{2}-2 \% \mathrm{DAP}$ & 782 & 1631 & 32.4 \\
\hline $\mathrm{F}_{3}-1 \% \mathrm{KNO}_{3}$ & 833 & 1828 & 31.2 \\
\hline $\mathrm{F}_{4}-2 \%$ 19-19-19 & 749 & 1569 & 32.4 \\
\hline $\mathrm{SEm} \pm$ & 23 & 55 & 0.70 \\
\hline $\mathrm{CD}(\mathrm{p}=0.05)$ & 67 & 161 & NS \\
\hline $\mathrm{CV}(\%)$ & 10.4 & 11.5 & 7.6 \\
\hline \multicolumn{4}{|l|}{ Interaction $(\mathbf{I} \times \mathbf{F})$ : } \\
\hline $\mathrm{SEm} \pm$ & 46 & 110 & 1.4 \\
\hline $\mathrm{CD}(\mathrm{p}=0.05)$ & NS & NS & NS \\
\hline
\end{tabular}


Table.4 Effect of irrigation and foliar nutrition on nutrient uptake of blackgram

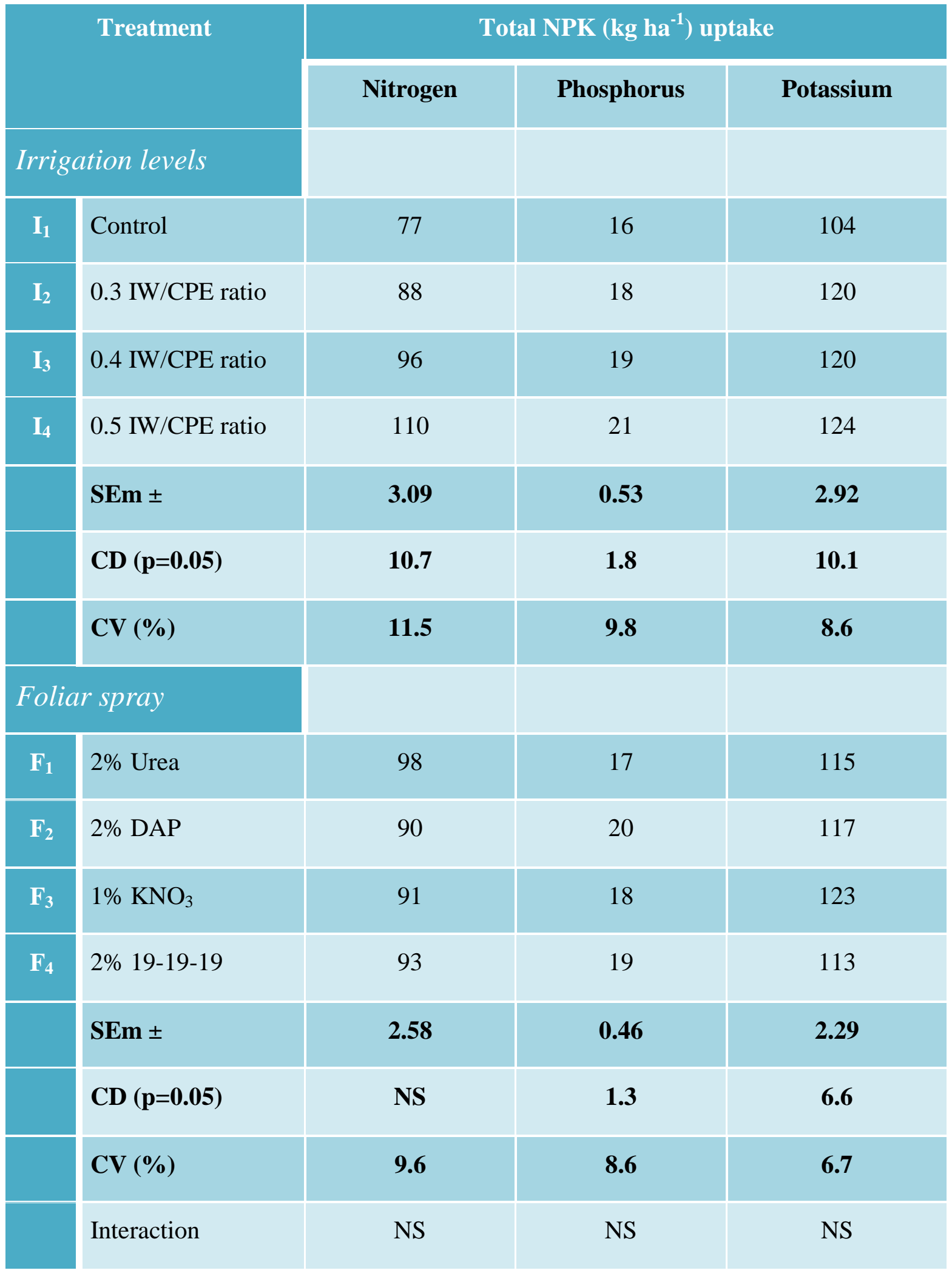




\section{Nutrient uptake}

Among the main plot treatments, irrigation at $0.5 \mathrm{IW} / \mathrm{CPE}$ ratio recorded the highest nitrogen and phosphorus uptake (110 and 21 $\mathrm{kg} \mathrm{ha}^{-1}$ ) which was significantly superior over all other treatments and the lowest nitrogen and phosphorus uptake (77 and $16 \mathrm{~kg} \mathrm{ha}^{-1}$ ) was recorded in control plot. The influence of foliar nutrition on nitrogen uptake was found to be non-significant. Foliar spray with $2 \%$ urea recorded the highest nitrogen uptake (98 $\left.\mathrm{kg} \mathrm{ha}^{-1}\right)$ and the lowest nitrogen uptake $(90 \mathrm{~kg}$ $\mathrm{ha}^{-1}$ ) was recorded in foliar spray of $2 \%$ DAP twice at pre-flowering and pod filling stages. The influence of irrigation and foliar nutrition on phosphorus and potassium uptake was found to be significant (Table 4). Among the sub plot treatments, foliar application of $2 \%$ DAP recorded significantly the highest phosphorus uptake $\left(20 \mathrm{~kg} \mathrm{ha}^{-1}\right)$ and the lowest phosphorus uptake $\left(17 \mathrm{~kg} \mathrm{ha}^{-1}\right)$ was observed in foliar spray of $2 \%$ urea twice at preflowering and pod filling stages.

Among the main plot treatments, irrigation at $0.5 \mathrm{IW} / \mathrm{CPE}$ recorded the highest potassium uptake $\left(124 \mathrm{~kg} \mathrm{ha}^{-1}\right)$ which was on a par with 0.4 IW/CPE and 0.3 IW/CPE and significantly superior over control plot. The lowest potassium uptake $\left(104 \mathrm{~kg} \mathrm{ha}^{-1}\right)$ was recorded in control plot. Foliar spray with $1 \%$ $\mathrm{KNO}_{3}$ recorded the highest potassium uptake $\left(123 \mathrm{~kg} \mathrm{ha}^{-1}\right)$ which was comparable with $2 \%$ DAP and significantly superior to foliar spray of $2 \%$ 19-19-19. The lowest potassium uptake $\left(113 \mathrm{~kg} \mathrm{ha}^{-1}\right)$ was recorded in foliar spray with 2 \% 19-19-19 which was comparable with foliar application of $2 \%$ DAP and $2 \%$ urea twice at pre-flowering and pod filling stages. The interaction effect of irrigation levels and foliar nutrition on nitrogen, phosphorus and potassium uptake was found to be non-significant.

The increase in irrigation frequency resulted in higher solubility of nutrients and higher uptake. Arya et al., (2005) reported that scheduling irrigation to chickpea at 0.9 IW/CPE ratio showed significantly higher N, $\mathrm{P}$ and $\mathrm{K}$ uptake by seed and stover and was at par with $0.7 \mathrm{IW} / \mathrm{CPE}$ ratio. The significant effect of foliar nutrition on nutrient uptake might be due to its easy availability and absorption of nutrients under foliar spray without spending much energy for their transport and without any loss in transit (Srivastava and Srivastava, 1994). The results were in corroboration with Kuttimani and Velayutham (2011a) and Venkatesh and Basu (2011).

Based on the results summarized above it is concluded that one irrigation given at vegetative stage (0.5 IW/CPE ratio) recorded the highest growth parameters, yield and yield attributes and also nutrient uptake over the one irrigation given at flowering and pod filling stages (0.4 and $0.3 \mathrm{IW} / \mathrm{CPE}$ ratios). Foliar spray of $1 \% \mathrm{KNO}_{3}$ recorded the highest growth and yield parameters over $2 \%$ urea, $2 \%$ DAP and $2 \%$ 19-19-19.

\section{References}

Agriculture action plan, 2015-16. Crop wise targeted area, productivity and production for 2015-16. Department of Agriculture, Andhra Pradesh. 20.

Anbumani S, Chandrasekhran B, Rajendran $P$ and Velayutham K 2003. Studies on nitrogen management in greengram. Legume Research. 26(1): 51-53.

Arya RL, Lalit Kumar, Singh KK and Kushwaha BL 2005. Effect of fertilizers and tillage management in rice (Oryza sativa) - chickpea (Cicer arietinum L.) cropping system under varying irrigation schedules. Indian Journal of Agronomy. 50(4): 256-259.

Beg MZ, Sohrab Ahmad and Deepak Kumar Srivastava 2013. Foliar application of potassium on urdbean. Indian Journal of Agricultural Sciences. 2(2): 67-70. 
Dabhi BM, Patel JC and Solanki RM 1998. Response of summer greengram to irrigation methods and varying moisture regimes. Legume Research. 21(2): 96100 .

Department of Agriculture and Co-operation, Government of Andhra Pradesh. 2015.

Jayarami Reddy P, Narasimha Rao KL and Mahalakshmi BK 2004. Effect of different chemicals on growth, yield and yield attributes of pigeonpea in vertisols. Annual Review of Plant Physiology. 17(2): 120-124.

Kadam JR, Pawar SU and Patil SR 2008. Effect of water soluble phosphatic fertilizers on chemical properties of soil and yield of soybean. Journal of Maharashtra Agricultural Universities. 339(2): 151-153.

Krishnamurthy SK and Ramulu SE 2007. Yield and yield attributes of bengalgram as influenced by time of sowing and number of irrigations during rabi season. Crop Research. 33(1, 2 \& 3): 65-67.

Kuttimani R and Velayutham A 2011a. Foliar application of nutrients enhances the yield attributes and nutrient uptake of green gram. Agricultural Science Digest. 31(3): 202-205.

Mustafa MN, Karuna Sagar G, Chandrika V, Reddy PM 2008. Growth and yield of chickpea as influenced by irrigation and nutrient management. Legume Research. 31(3): 221-223.

Parasuraman P 2001. Effect of seed pelleting with diammonium phosphate and potassium dihydrogen phosphate and foliar spray with diammonium phosphate on growth and yield of rainfed cowpea (Vigna unguiculata L.). Indian Journal of Agronomy. 45(1): 131-134.

Srivastava GP and Srivastava VC 1994. Effect of irrigation and foliar spray of nutrients on growth and seed yield of gram (Cicer arietinum L.). Indian Journal of Agricultural Sciences. 64(4): 219-222.

Subramani M and Solaimalai A 2000. Influence of plant populations and methods of nutrient application on growth and yield of blackgram. Legume Research. 23(3): 197-198.

Thiyageswari S and Ranganathan G 1999. Micronutrients and cytozyme on grain yield and dry matter production of soybean. Madras Agricultural Journal. 86(7- 9): 496-498.

Venkatesh MS and Basu PS 2011. Effect of foliar application of urea on growth, yield and quality of chickpea under rainfed conditions. Journal of Food Legumes. 24(2): 110-112.

\section{How to cite this article:}

Kaviti Vijaya Lakshmi, S. Prathibha Sree, N. Venkata Lakshmi, P. Madhu Vani and K. Chandrasekhar. 2018. Effects of Irrigation and Foliar Nutrition on Growth, Yield and Nutrient Uptake of Blackgram (Vigna mungo L.). Int.J.Curr.Microbiol.App.Sci. 7(06): 2425-2432. doi: https://doi.org/10.20546/ijcmas.2018.706.288 